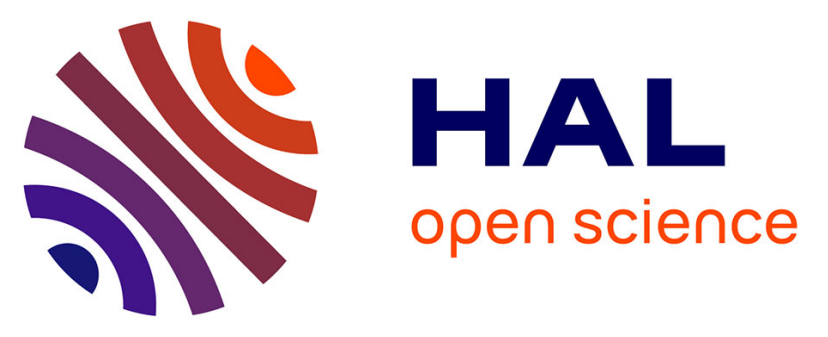

\title{
Relation of Body Mass Index to Outcomes in Patients With Heart Failure Implanted With Left Ventricular Assist Devices
}

\author{
Vincent Galand, Erwan Flécher, Bernard Lelong, Céline Chabanne, Marion \\ Charton, Céline Goéminne, André Vincentelli, Jean Porterie, Clement \\ Delmas, Karine Nubret, et al.
}

\section{To cite this version:}

Vincent Galand, Erwan Flécher, Bernard Lelong, Céline Chabanne, Marion Charton, et al.. Relation of Body Mass Index to Outcomes in Patients With Heart Failure Implanted With Left Ventricular Assist Devices. American Journal of Cardiology, 2020, 133, pp.81-88. 10.1016/j.amjcard.2020.07.045 . hal-02960938

\section{HAL Id: hal-02960938 \\ https://hal.science/hal-02960938}

Submitted on 6 Nov 2020

HAL is a multi-disciplinary open access archive for the deposit and dissemination of scientific research documents, whether they are published or not. The documents may come from teaching and research institutions in France or abroad, or from public or private research centers.
L'archive ouverte pluridisciplinaire HAL, est destinée au dépôt et à la diffusion de documents scientifiques de niveau recherche, publiés ou non, émanant des établissements d'enseignement et de recherche français ou étrangers, des laboratoires publics ou privés. 


\section{Relation of Body Mass Index to Outcomes in Patients with Heart Failure Implanted}

with Left Ventricular Assist Devices.

\section{Running title: Impact on BMI in LVAD recipients}

Authors: Vincent Galand, MD, ${ }^{a}$ Erwan Flécher, $\mathrm{MD}, \mathrm{PhD},{ }^{\mathrm{a}}$ Bernard Lelong, $\mathrm{MD},{ }^{\mathrm{a}}$ Céline Chabanne, MD, ${ }^{\mathrm{a}}$ Marion Charton, MD, ${ }^{\mathrm{a}}$ Céline Goéminne, MD, ${ }^{\mathrm{b}}$ André Vincentelli, MD, $\mathrm{PhD},{ }^{\mathrm{b}}$ Jean Porterie, MD, ${ }^{\mathrm{c}}$ Clément Delmas MD,${ }^{\mathrm{c}}$ Karine Nubret, MD, ${ }^{\mathrm{d}}$ Mathieu Pernot, $\mathrm{MD}^{\mathrm{d}}$ Michel Kindo, MD, PhD, ${ }^{\mathrm{e}}$ Tam Hoang Minh, MD, ${ }^{\mathrm{e}}$ Philippe Gaudard, MD, ${ }^{\mathrm{f}}$ Philippe Rouvière, MD, ${ }^{\mathrm{f}}$ Thomas Sénage, MD, ${ }^{\mathrm{h}}$ Magali Michel, MD, ${ }^{\mathrm{h}}$ Aude Boignard, MD, ${ }^{\mathrm{i}}$ Olivier Chavanon, MD, PhD, ${ }^{\mathrm{i}}$ Constance Verdonk, MD ${ }^{\mathrm{j}}$ Marylou Para, MD, ${ }^{\mathrm{j}}$ Edeline Pelcé, MD, ${ }^{\mathrm{k}}$ Vlad Gariboldi, MD, PhD, ${ }^{k}$ Matteo Pozzi, MD, ${ }^{1}$ Jean-François Obadia, MD, PhD, ${ }^{1}$ PierreYves Litzler, $\mathrm{MD}, \mathrm{PhD}^{\mathrm{m}}$ Frédéric Anselme, $\mathrm{MD},{ }^{\mathrm{m}}$ Katrien Blanchart, $\mathrm{MD},{ }^{\mathrm{n}}$ Gerard Babatasi, $\mathrm{MD}, \mathrm{PhD},{ }^{\mathrm{n}}$ Fabien Garnier, MD,${ }^{\mathrm{o}}$ Marie Bielefeld, MD, ${ }^{\mathrm{o}}$ Costin Radu, MD, ${ }^{\mathrm{p}}$ David Hamon, $\mathrm{MD}, \mathrm{PhD},{ }^{\mathrm{p}}$ Thierry Bourguignon, $\mathrm{MD},{ }^{\mathrm{q}}$ Thibaud Genet $\mathrm{MD},{ }^{\mathrm{q}}$ Romain Eschalier, MD, PhD, ${ }^{\mathrm{r}}$ Nicolas D'Ostrevy, MD, ${ }^{\mathrm{r}}$ Marie-Cécile Bories, MD, ${ }^{\mathrm{s}}$ Emilie Varlet, MD, ${ }^{\mathrm{s}}$ Fabrice Vanhuyse, MD, ${ }^{t}$ Nicolas Sadoul, MD, PhD ${ }^{t}$, Christophe Leclercq, MD, PhD, ${ }^{a}$ Raphaël P. Martins, MD, $\mathrm{PhD},{ }^{\mathrm{a}}$

AFFILIATIONS. ' Univ Rennes, CHU Rennes, INSERM, LTSI - UMR 1099, F-35000 Rennes, France; ${ }^{\mathrm{b}} \mathrm{CHU}$ Lille, Institut Coeur-Poumons, Cardiac Intensive Care Unit, Department of Cardiology, Department of Cardiac Surgery, Lille, France; ${ }^{\mathrm{c} C e n t r e ~ H o s p i t a l i e r}$ Universitaire de Toulouse, Toulouse, France; ${ }^{\mathrm{d} H o ̂ p i t a l ~ C a r d i o l o g i q u e ~ d u ~ H a u t-L e ́ v e ̂ q u e, ~}$ LIRYC institute, Université Bordeaux, Bordeaux, France; éDépartement de chirurgie cardiovasculaire, hôpitaux universitaires de Strasbourg, Strasbourg, France; ${ }^{\mathrm{f}}$ Department of Anesthesiology and Critical Care Medicine, PhyMedExp, University of Montpellier, INSERM, CNRS, CHU Montpellier, Montpellier, France; ' Department of Cardiac Surgery, Anesthesiology and Critical Care Medicine, Arnaud de Villeneuve Hospital, CHRU Montpellier, Montpellier, France; 'hepartment of Cardiology and Heart Transplantation Unit, CHU Nantes, France; iDepartment of Cardiology and Cardiovascular Surgery, CHU Michallon, Grenoble, France; i Department of Cardiology and cardiac surgery, BichatHospital, Paris, France; ${ }^{k}$ Department of Cardiac Surgery, La Timone Hospital, Marseille, France ${ }^{l}$ Department of Cardiac Surgery, "Louis Pradel" Cardiologic Hospital, Lyon, France; mDepartment of Cardiology and Cardiovascular Surgery, Hospital Charles Nicolle, Rouen, France; ${ }^{n}$ Department of Cardiology and Cardiac Surgery, University of Caen and University Hospital of Caen, France; ${ }^{\circ}$ Department of Cardiology and cardiac surgery, University Hospital, Dijon, France; ${ }^{\mathrm{P} D e p a r t m e n t}$ of Cardiology and Cardiac Surgery, AP-HP CHU Henri Mondor, Créteil, France; ${ }^{\mathrm{q}}$ Department of Cardiology and Cardiac Surgery, Tours University Hospital, Tours, France; ${ }^{\mathrm{r}} \mathrm{CHU}$ Clermont-Ferrand, Cardiology Department, Clermont-Ferrand, France; 'European Georges Pompidou Hospital, Cardiology Department, Paris, France; tDepartment of Cardiology and Cardiac Surgery, CHU de Nancy, Hopital de Brabois, Nancy, France.

CORRESPONDING AUTHOR Vincent Galand, Service de Cardiologie et Maladies Vasculaires, CHU de Rennes, 2 rue Henri Le Guilloux, 35000 Rennes, France. Tel: + 33299 282 507, Fax: +33 299282 529, E-mail: vincent.galand35@gmail.com 


\section{Abstract:}

We aimed at characterizing the impact of low and high Body Mass Index (BMI) on outcomes after Left-Ventricular Assist Device (LVAD) surgery and define the predictors of mortality in patients with abnormal BMI (low/high). This study was conducted in 19 centers between 2006 and 2016. Patients were divided based on their baseline BMI into 3 groups of BMI: low $\left(\mathrm{BMI} \leq 18.5 \mathrm{~kg} / \mathrm{m}^{2}\right)$; normal $\left(\mathrm{BMI}=18.5-24.99 \mathrm{~kg} / \mathrm{m}^{2}\right)$ and high $\left(\mathrm{BMI} \geq 25 \mathrm{~kg} / \mathrm{m}^{2}\right)$ (including overweight $\left(\mathrm{BMI}=25-29.99 \mathrm{~kg} / \mathrm{m}^{2}\right)$ and obesity $\left.\left(\mathrm{BMI} \geq 30 \mathrm{Kg} / \mathrm{m}^{2}\right)\right)$. Among 652 patients, 29 (4.4\%), 279 (42.8\%) and $344(52.8 \%)$ had a low, normal and high BMI, respectively. Patients with high BMI were significantly more likely men, with more co-morbidities and more history of ventricular/supra-ventricular arrhythmias before LVAD implantation. Patients with abnormal BMI had significantly lower survival than those with normal BMI. Notably, those with low BMI experienced the worst survival whereas overweight or obese patients had similar survival. Four predictors of mortality for LVAD candidates with abnormal BMI were defined: total bilirubin $\geq 16 \mu \mathrm{mol} / \mathrm{L}$ prior to $\mathrm{LVAD}$, hypertension, destination therapy and cardiac surgery with LVAD. Depending on the number of predictor per patients, those with abnormal BMI may be divided in 3 groups of 1-year mortality risk, i.e. low (0-1 predictor: $29 \%$ and $31 \%$ ), intermediate (2-3 predictors, $51 \%$ and $52 \%$, respectively) and high (4 predictors: 83\%). In conclusion, LVAD recipients with abnormal BMI experience lower survival, especially underweight patients. Four predictors of mortality have been identified for LVAD population with abnormal BMI, differentiating those a low, intermediate and high risks of death.

Keywords: Body mass index, Left ventricular assist device, mortality. 


\section{INTRODUCTION}

Left ventricular assist device (LVAD) implantation has been shown to improve survival in patients with refractory heart failure (HF) (1-3). However, an optimal LVAD candidate selection is crucial to expect favorable outcomes after pump implantation. It has been well established that obesity increases the morbidity and mortality in patients scheduled for cardiac surgery (4). Conversely, the impact of body mass index (BMI) on outcomes after LVAD implantation seems unclear. Indeed, prior published works did not observe that obesity or extreme obesity were associated with higher mortality among the LVAD population (5-9) but may predispose to an increased rate of adverse events $(5 ; 8 ; 10)$. In opposite, limited data have shown that small body size was correlated with higher mortality in LVAD recipients (11-12), whereas a larger study observed that low BMI did not impact the survival in patients with LVAD (9). In this large multicenter cohort, we aimed at better characterizing the impact of low and high BMI on outcomes after LVAD surgery and define the predictors of overall mortality in patients with abnormal BMI (low or high) scheduled for LVAD implantation.

\section{METHODS}

The ASSIST-ICD (Clinicaltrials.gov identifier: NCT02873169) is a retrospective, multicenter observational study of durable mechanical circulatory support devices implanted in patients treated in 19 tertiary care centers in France. The study methods have been previously reported (13). Briefly, patients aged $\geq 18$ years implanted with axial HeartMate 2 (Abbott, Chicago, Illinois), Jarvik 2000 (Jarvik Heart, Inc., New York, New York) or centrifugal HeartWare (Medtronic, Minneapolis, Minnesota) pumps between February 2006 and December 2016 were included. Exclusion criteria were total artificial heart placement or pulsatile flow LVAD, history of heart transplant, and receipt of a VentrAssist device (Ventracor, Chatswood, NSW, Australia). This study was approved by the regional ethics 
committees, the French Advisory Committee on the Treatment of Research Information in the Field of Health (CCTIRS), and the French National Commission of Informatics and Civil Liberties (CNIL). A non-opposition letter was sent to the patients, as requested by French authorities for retrospective studies.

Baseline data - including demographic characteristics, cardiac disease, and heart failure history, echocardiography- were collected from hospital files for all patients. Perioperative data (such as the necessity of a combined surgery) were also collected.

Follow-up was performed according to each institution's protocols. The LVAD controller monitor was checked during every clinical visit in each center, according to the state-of-theart standard of care for LVAD recipients. The last day of follow-up was December 31st, 2016, the date of heart transplantation, or death, whichever occurred first.

For the purpose of this study, the overall population was divided based on their baseline BMI into 3 groups: low (BMI $\left.\leq 18.5 \mathrm{~kg} / \mathrm{m}^{2}\right)$; normal (BMI: $18.5-24.99 \mathrm{~kg} / \mathrm{m}^{2}$ ) and high (BMI $\geq 25 \mathrm{~kg} / \mathrm{m}^{2}$ ) BMI (including overweight (BMI: $25-29.99 \mathrm{~kg} / \mathrm{m}^{2}$ ) and obese (BMI $\geq 30 \mathrm{Kg} / \mathrm{m}^{2}$ ) patients). Of note, patients were grouped according to BMI based on the World Health Organization classification (14).

The primary endpoint of the study was all-cause mortality. Deaths were classified as cardiovascular death (cardiac or vascular cause), non-cardiac death, or unknown cause. Secondary endpoints included heart transplantation and LVAD related complications (i.e. thrombosis, stroke, bleeding, driveline infection or pump replacement).

Normally distributed variables were expressed as means \pm SD and compared using Student's t-test. Non-normally distributed variables were expressed as median and interquartile ranges and compared using Mann-Whitney's U-test. Categorical variables were expressed as counts and percentages and were compared using the Chi-square test or exact 
Fisher test when needed. Differences between groups were quantified by using ANOVA and chi-square tests when appropriate. Survival analysis was performed using Kaplan-Meier estimates, and log-rank tests were used to compare groups. A $p$-value $<0.05$ was considered statistically significant. The optimal cut-off values were defined using receiver-operating characteristic curves and the maximum Youden's index (sensitivity + specificity). Predictors of mortality were analyzed using univariate and multivariable proportional hazard models. The proportional hazard assumption was tested and verified for each covariate. Variables with p-values $<0.05$ in univariate analysis were included in the multivariable analysis. The analyses were performed with the SPSS statistical package, version 11.0 (SPSS Inc., Chicago, IL).

\section{RESULTS}

From 2006 to 2016, a total of 659 patients were implanted with a continuous-flow LVAD and included in the study. Among these, 7 patients were excluded (3 patients received a VentrAssist and 4 patients died during the LVAD surgery). A total of 652 patients were included in the final analysis and followed during 9.1 (2.5-22.1) months. Among this population, a total of $29(4.4 \%), 279(42.8 \%)$ and $344(52.8 \%)$ patients were classified in the low, normal and high BMI groups, respectively. Of note, in the high BMI group, 241 (37.0\%) patients were overweight with a BMI ranging from 25 to $29.99 \mathrm{~kg} / \mathrm{m}^{2}$ and 103 (15.8\%) were obese with a $\mathrm{BMI} \geq 30 \mathrm{~kg} / \mathrm{m}^{2}$. The description of the study population depending on the BMI is represented in Figure 1, panel A and B. The baseline characteristics of the 3 groups are detailed in Table 1. Patients with high BMI (i.e. $\geq 25 \mathrm{~kg} / \mathrm{m}^{2}$ ) were significantly more likely men, with more comorbidities and more history of ventricular/supra-ventricular arrhythmias before LVAD implantation. Conversely, those with normal BMI had shorter HF duration with 
less dilated left ventricle and were less likely to receive optimal HF drugs before LVAD surgery compared to the LVAD recipients with non-normal BMI.

Interestingly, patients with abnormal BMI (i.e. low and high groups) experienced a significantly longer stay in ICU compared to those with normal BMI. However, no difference was found regarding total in hospital stay but patients with low BMI had a numerically longer total hospital stay (Table 1). During the study period, patients with low, normal and high BMI had a similar rate of LVAD related thrombosis, stroke, bleeding, and driveline infection. However, those with high BMI exhibited a non-significant trend towards higher episode of thrombosis and stroke (Table 2). Conversely, those with low BMI presented numerically more cerebral bleeding event. Importantly, no pump replacement was performed in the low BMI group whereas $14.8 \%$ of the patients with high BMI had device exchange during the study period $(\mathrm{p}<0.001)$.

During a 9.1 (2.5-22.1) months follow-up, a total of 291 patients died, 14 (48.3\%), 105 (37.6\%) and $172(50.0 \%)$ in the low, normal and high BMI groups, respectively ( $\mathrm{p}=0.008)$. Additionally, there was a trend toward a higher cause of cardiac death in the group with high BMI and non-cardiac death in the low BMI group. Lastly, although being non-significant, underweight patients were numerically less likely to receive heart transplantation during follow-up. As illustrated in Figure 2 (panel A) patients with abnormal BMI had significantly lower survival than those with normal BMI. Interestingly, LVAD recipients with low BMI experienced the worst survival whereas overweight or obese patients had similar intermediate survival (Figure 2, panel B)

Multivariable analysis identified four significant predictors of overall mortality among the population with abnormal BMI scheduled for LVAD implantation: total bilirubin 
$\geq 16 \mu \mathrm{mol} / \mathrm{L}$ prior to $\mathrm{LVAD}$, systemic hypertension at baseline, destination therapy as LVAD indication and any cardiac surgery combined with LVAD (Table 3). Notably, each predictor increases by 2 -fold the risk of death. The survival depending on the number of predictors per patient is represented in Figure $\mathbf{3}$ and shows a gradual increase in the risk of death with increasing number of predictors. Interestingly, patients with abnormal BMI and 0 or 1 predictor exhibited the same 36-months survival than those with normal BMI. However, LVAD recipients with 2 or 3 predictors experienced lower but similar survival. Lastly those with 4 predictors had the worst outcomes. To summarize, patients with abnormal BMI can be divided in 3 groups of risk depending on the number of predictor factors per patient: i.e. $0-1$ predictor $=$ low risk of 1 -year mortality $(29 \%$ and $31 \%$, respectively), $2-3$ predictors $=$ intermediate risk of 1 -year mortality ( $51 \%$ and $52 \%$, respectively) and 4 predictors $=$ high risk of 1-year mortality (83\%).

\section{DISCUSSION}

The major findings of this multicenter study are: 1) More than half of the LVAD candidates have an abnormal BMI; 2) LVAD recipients with abnormal BMI have poor outcomes, especially those with low BMI; 3) Total bilirubin prior to LVAD, hypertension, destination therapy and any cardiac surgery combined with LVAD are the 4 predictors of mortality among LVAD candidates with abnormal BMI; and 4) There was a gradually increased risk of mortality depending on the number of predictors per patient.

It has been well established that overweight and obesity are associated with an increased risk of HF (15). Additionally, in patients with end-stage HF, the incidence of obesity may range from $25 \%$ to $36 \%$ that considerably reduces the probability of heart transplantation (16-17) and leads to a higher post-transplant morbidity/mortality (18). 
Similarly, underweight BMI $\left(<18.5 \mathrm{~kg} / \mathrm{m}^{2}\right)$ can limit access to cardiac transplantation due to a lower probability of donor-recipient size matching. Additionally, an analysis from the International Society for Heart and Lung Transplantation registry observed that an underweight BMI leads to an increased risk of post-operative mortality and serious adverse events after heart transplantation (19). These results suggest that in patients with end-stage HF and abnormal BMI, LVAD implantation could be an attractive alternative option, especially since the smaller size of new generation devices allows their use in a larger population. In our study, we showed that more than half of the LVAD recipients had an abnormal BMI at the time of pump implantation. Interestingly, this population had a 2-fold longer HF duration before LVAD implantation and more likely received optimal HF drugs. These differences may suggest the challenging management of these patients in France, with a preference for longer drug strategy and a potential reluctance for an early LVAD implantation compared to patients with normal BMI.

Our findings show that patients with abnormal BMI experience lower survival than those with normal BMI and especially those with underweight BMI. Discrepant results have been published thus far and prior works did not show that obesity decreased survival among LVAD recipients (5-9). However, a recent meta-analysis suggested that obese patients have similar long-term survival after LVAD implantation when compared to non-obese patients (20). In our study, we showed that patients with high BMI have advanced cardiomyopathy, more dilated left ventricle with more co-morbidities and may potentially explain the higher mortality in this population. Additionally, we observed that these patients more likely experienced a pump replacement and had numerically more pump thrombosis and stroke events, possibly leading to increased mortality. These findings are supported by several studies demonstrating that obesity was associated with an increased risk of LVAD 
complications (8-9). However, as previously described, we did not show a relationship between obesity and LVAD-related infections (21).

Our study also highlights that patients with underweight BMI have worse outcomes. Conversely, a Japanese study has reported excellent outcomes in patients with a small body surface area and receiving an LVAD, probably due to the different patient populations and their extensive experience with these smaller patients (22). However, previous work showed that patients with small body size had higher post-operative mortality and lower long-term survival (11). Indeed, despite the development of smaller devices, a minimal body surface area is still required by manufacturers to avoid misalignment of the inflow connector or mechanical compression of cardiovascular structures (23). This mismatch between BMI and LVAD size could possibly explain the worst outcomes. It is also plausible that underweight patients may have the unnecessary metabolic reserves to overcome the further increased catabolic stress resulting from a stressful surgery and long-term life with LVAD (24).

In this study, 4 predictors of mortality in LVAD recipients with abnormal BMI were defined. We found that systemic hypertension at baseline was a predictor of death. Indeed, hypertension may impact outcomes in patients with LVAD by decreasing pump flow, increasing LV filling pressure leading to worsening heart failure symptoms and promoting denovo aortic insufficiency (25). Additionally, we observed that a high total bilirubin level (i.e. $\geq 16 \mu \mathrm{mol} / \mathrm{L}$ ) independently impacts long-term survival. This parameter is known to be a marker of chronic congestion due to right ventricular dysfunction prior to LVAD implantation and indicates a more severe end-stage HF with multiple organ failure (26). We also shown that any cardiac surgery combined with LVAD predicted higher mortality in patients with abnormal BMI, which is concordant with previous data showing that this parameter was an independent predictor of post-operative mortality (27). Indeed, LVAD candidates requiring a 
combined surgery usually require a longer and more complex surgery possibly leading to myocardial injuries. Lastly, we found that destination therapy indication was associated with a higher risk of death, since these patients are not candidates for heart transplantation. Importantly, we highlighted that the number of predictors per patient strongly impacts survival. Indeed, patients with abnormal BMI and 0 or 1 predictor are at low risk of death, those with 2 or 3 predictors have an intermediate risk of death and patients with 4 predictors may be defined at a high risk of death. Nevertheless, a small panel of abnormal BMI patients was classified in this group and this result should be interpreted cautiously.

Our observational study has some limitations, including its retrospective design that may have affected the results. Additionally, we cannot provide an extensive description of the nutritional status (i.e. albumin or pre-albumin parameters) among obese or underweight patients. Furthermore, it has been established that LVAD implantation is associated with long-term improvement in nutrition (28). Unfortunately, we did not collect the evolution of the BMI after LVAD implantation and consequently, we cannot investigate the impact of the BMI normalization on outcomes in LVAD patients. Also, we acknowledge that these findings reflect clinical practice in France but may not necessarily be extended to other populations. Lastly, we did not evaluate the impact of BMI in patients scheduled for HeartMate 3. Further studies are warranted to assess the outcomes of abnormal BMI in this population.

In conclusion, LVAD candidate with overweight/underweight BMI is extremely common in clinical practice. Importantly, LVAD recipients with abnormal BMI experience lower survival, especially those with underweight BMI. Four predictors of mortality have been identified for the LVAD population with abnormal BMI, differentiating those a low, intermediate and high risk of death. 
ACKNOWLEDGMENT: This research was supported by the French Federation of Cardiology.

FUNDING: This research was supported in part by the French Federation of Cardiology. 


\section{REFERENCES}

1- Pagani FD, Miller LW, Russell SD, Aaronson KD, John R, Boyle AJ, Conte JV, Bogaev RC, MacGillivray TE, Naka Y, Mancini D, Massey HT, Chen L, Klodell CT, Aranda JM, Moazami N, Ewald GA, Farrar DJ, Frazier OH; HeartMate II Investigators. Extended mechanical circulatory support with a continuous-flow rotary left ventricular assist device. J Am Coll Cardiol. 2009;54:312-321.

2- Miller LW, Pagani FD, Russell SD, Boyle AJ, Aaronson KD, Conte JV, Naka Y, Mancini D, Delgado RM, MacGillivray TE, Farrar DJ, Frazier OH; HeartMate II Clinical Investigators. Use of a continuous-flow device in patients awaiting heart transplantation. N Engl J Med. 2007; 357: 885-896.

3- Slaughter MS, Rogers JG, Milano CA, Russell SD, Conte JV, Feldman D, Sun B, Tatooles AJ, Delgado RM 3rd, Long JW, Wozniak TC, Ghumman W, Farrar DJ, Frazier $\mathrm{OH}$; HeartMate II Investigators. Advanced heart failure treated with continuous-flow left ventricular assist device. N Engl J Med. 2009;361(23):2241-2251.

4- Ghanta RK, Lapar DJ, Zhang Q, Devarkonda V, Isbell JM, Yarboro LT, Kern JA, Kron IL, Speir AM, Fonner CE, Ailawadi G. Obesity Increases Risk-Adjusted Morbidity, Mortality, and Cost Following Cardiac Surgery. J Am Heart Assoc. 2017 ; 8;6(3):e003831

5- Lee AY, Tecson KM, Lima B, Shaikh AF, Collier J, Still S, Baxter R, DiMaio JM, Felius J, Carey SA, Gonzalez-Stawinski GV, Nauret R, Wong M, Hall SA, Joseph SM. Durable left ventricular assist device implantation in extremely obese heart failure patients. Artif Organs. 2019;43(3):234-241.

6- Volkovicher N, Kurihara C, Critsinelis AC, Kawabori M, Sugiura T, Manon MA 2nd, Civitello AB, Morgan JA. Effect of obesity on outcomes in patients who undergo implantation of a continuous-flow left ventricular assist device. J Artif Organs. 2018;21(3):397 
7- Go PH, Nemeh HW, Borgi J, Paone G, Morgan JA. Effect of Body Mass Index on Outcomes in Left Ventricular Assist Device Recipients. J Card Surg. 2016;31(4):242-247

8- Brewer RJ, Lanfear DE, Sai-Sudhakar CB, Ravi Y, Farrar DJ, Slaughter MS. Extremes of body mass index do not impact mid-term survival after continuous-flow left ventricular assist device implantation. J Heart Lung Transplant. 2012;31(2):167-172

9- Clerkin KJ, Naka Y, Mancini DM, Colombo PC, Topkara VK. The Impact of Obesity on Patients Bridged to Transplantation With Continuous-Flow Left Ventricular Assist Devices. JACC Heart Fail. 2016;4(10):761-768.

10- Forest SJ, Xie R, Kirklin JK, Xia Y, Dipchand AI, Sivathasan C, Merry C, Lund LH, Kormos R, Hannan MM, Nakatani T, Jorde U, Goldstein DJ. Impact of body mass index on adverse events after implantation of left ventricular assist devices: An IMACS registry analysis. J Heart Lung Transplant. 2018;37(10):1207-1217

11- Volkovicher N, Kurihara C, Critsinelis A, Kawabori M, Sugiura T, Manon MA 2nd, Civitello AB, Morgan JA. Outcomes in patients with advanced heart failure and small body size undergoing continuous-flow left ventricular assist device implantation. $J$ Artif Organs. 2018;21(1):31-38.

12- Komoda T, Drews T, Hetzer R, Lehmkuhl HB. Lower body surface area is highly related to mortality due to stroke or systemic bleeding in patients receiving an axial flow blood pump as a left ventricular assist device. Eur J Cardiothorac Surg. 2013;43(5):1036-1042.

13-Galand V, Flécher E, Auffret V, Boulé S, Vincentelli A, Dambrin C, Mondoly P, Sacher F, Nubret K, Kindo M, Cardi T, Gaudard P, Rouvière P, Michel M, Gourraud JB, Defaye P, Chavanon O, Verdonk C, Ghodbane W, Pelcé E, Gariboldi V, Pozzi M, Obadia JF, Litzler PY, Anselme F, Babatasi G, Belin A, Garnier F, Bielefeld M, Hamon D, Radu C, Pierre B, Bourguignon T, Eschalier R, D'Ostrevy N, Bories MC, Marijon E, Vanhuyse F, Blangy H, Verhoye JP, Leclercq C, Martins RP; ASSIST-ICD Investigators. Predictors 
and Clinical Impact of Late Ventricular Arrhythmias in Patients with Continuous-Flow Left Ventricular Assist Devices. JACC Clin Electrophysiol. 2018;4(9):1166-1175

14- World Health Organization: BMI classification. Available from: http://apps.who.int/bmi/index.jsp? [2002 October 25, cited 2015 February 26].

15- Aune D, Sen A, Norat T, Romundstad P, Tonstad S, Vatten LJ. Body Mass Index, Abdominal Fatness, and Heart Failure Incidence and Mortality: A Systematic Review and Dose-Response Meta-Analysis of Prospective Studies. Circulation. 2016;133(7):639-649.

16- Mentz RJ, Kelly JP, von Lueder TG, Voors AA, Lam CS, Cowie MR, Kjeldsen K, Jankowska EA, Atar D, Butler J, Fiuzat M, Zannad F, Pitt B, O'Connor CM. Noncardiac comorbidities in heart failure with reduced versus preserved ejection fraction. J Am Coll Cardiol. 2014;64(21):2281-2293.

17- Weiss ES, Allen JG, Russel SD, Shah AS, Conte JV. Impact of recipient body mass index on organ allocation and mortality in orthotopic heart transplantation. J Heart Lung Transplant. 2009;28:1150-1157

18- Russo MJ, Hong KN, Davies RR, Chen JM, Mancini DM, Oz MC, Rose EA, Gelijns A, Naka Y. The effect of body mass index on survival following heart transplantation: do outcomes support consensus guidelines? Ann Surg. 2010;251(1):144-152.

19- Doumouras BS, Fan CS, Mueller B, Dipchand AI, Manlhiot C, Stehlik J, Ross HJ, Alba AC. The effect of pre-heart transplant body mass index on posttransplant outcomes: An analysis of the ISHLT Registry Data. Clin Transplant. 2019;33(7):e13621.

20- Khan MS, Yuzefpolskaya M, Memon MM, Usman MS, Yamani N, Garan AR, Demmer RT, Colombo PC. Outcomes associated with Obesity in Patients Undergoing Left Ventricular Assist Device Implantation: A Systematic Review and Meta-Analysis. ASAIO J. 2020;66(4):401-408. 
21- Tattevin P, Flécher E, Auffret V, Leclercq C, Boulé S, Vincentelli A, Dambrin C, Delmas C, Barandon L, Veniard V, Kindo M, Cardi T, Gaudard P, Rouvière P, Sénage T, Jacob N, Defaye P, Chavanon O, Verdonk C, Para M, Pelcé E, Gariboldi V, Pozzi M, Grinberg D, Savouré A, Litzler PY, Babatasi G, Belin A, Garnier F, Bielefeld M, Hamon D, Lellouche N, Bernard L, Bourguignon T, Eschalier R, D'Ostrevy N, Jouan J, Varlet E, Vanhuyse F, Blangy H, Martins RP, Galand V. Risk factors and prognostic impact of left ventricular assist device-associated infections. Am Heart J. 2019;214:69-76.

22- Ono M, Sawa Y, Nakatani T, Tominaga R, Matsui Y, Yamazaki K, Saiki Y, Niinami H, Matsumiya G, Arai H; Japanese HeartMate II Investigators. Japanese multicenter outcomes with the HeartMate II left ventricular assist device in patients with small Body surface area. Circ J. 2016;80:1931-1936.

23- Komoda T, Drews T, Hetzer R, Lehmkuhl HB. Lower body surface area is highly related to mortality due to stroke or systemic bleeding in patients receiving an axial flow blood pump as a left ventricular assist device. Eur J Cardiothorac Surg. 2013;43(5):1036-1042.

24- Gao M, Sun J, Young N, Boyd D, Atkins Z, Li Z, Ding Q, Diehl J, Liu H. Impact of Body Mass Index on Outcomes in Cardiac Surgery. $J$ Cardiothorac Vasc Anesth. 2016;30(5):1308-1316

25- Wasson LT, Yuzefpolskaya M, Wakabayashi M, Takayama H, Naka Y, Uriel N, Jorde UP, Demmer RT, Colombo PC. Hypertension: an unstudied potential risk factor for adverse outcomes during continuous flow ventricular assist device support. Heart Fail Rev. 2015;20(3):317-322.

26- Maxhera B, Albert A, Ansari E, Godehardt E, Lichtenberg A, Saeed D. Survival predictors in ventricular assist device patients with prior extracorporeal life support: selecting appropriate candidates. Artif Organs 2014;38:727-732 
27-Galand V, Flécher E, Auffret V, Pichard C, Boulé S, Vincentelli A, Rollin A, Mondoly P, Barandon L, Pernot M, Kindo M, Cardi T, Gaudard P, Rouvière P, Sénage T, Jacob N, Defaye P, Chavanon O, Verdonk C, Ghodbane W, Pelcé E, Gariboldi V, Pozzi M, Obadia JF, Savouré A, Anselme F, Babatasi G, Belin A, Garnier F, Bielefeld M, Hamon D, Lellouche N, Pierre B, Bourguignon T, Eschalier R, D'Ostrevy N, Bories MC, Marijon E, Vanhuyse F, Blangy H, Verhoye JP, Leclercq C, Martins RP. Early Ventricular Arrhythmias After LVAD Implantation Is the Strongest Predictor of 30-Day PostOperative Mortality. JACC Clin Electrophysiol. 2019;5(8):944-954

28-Genev I, Yost G, Gregory M, Gomez K, Pappas P, Tatooles A, Bhat G. Improved Nutrition Status in Patients With Advanced Heart Failure Implanted With a Left Ventricular Assist Device. Nutr Clin Pract. 2019;34(3):444-449 


\section{FIGURE LEGENDS}

Figure 1: Proportion of LVAD recipients with abnormal BMI. Panel A: Number of patients depending on the BMI. Panel B: Proportion of patients depending on the BMI

Figure 2: Survival curves. Panel A: Survival curves in patients with normal or abnormal BMI. Panel B: Survival curves between LVAD recipients with underweight, normal, overweight and obese BMI.

Figure 3: Survival curves depending on the number of predictors per patient among the LVAD population with abnormal BMI. 
Table 1: Baseline characteristics between patients with low, normal or high BMI

\begin{tabular}{|c|c|c|c|c|}
\hline Variable & 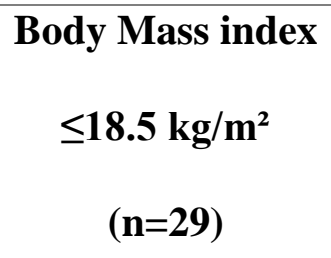 & $\begin{array}{l}\text { Body Mass index } \\
\begin{array}{c}18.5-24.99 \mathrm{~kg} / \mathrm{m}^{2} \\
(\mathrm{n}=279)\end{array}\end{array}$ & 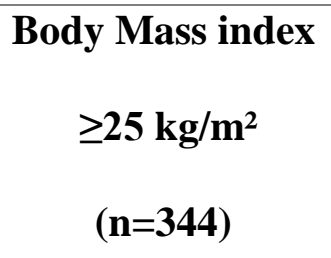 & $\begin{array}{c}\mathbf{p} \\
\text { Value }\end{array}$ \\
\hline Age, (years) & $58.2(53.4-64.8)$ & $59.8(50.0-67.1)$ & $59.9(52.2-65.9)$ & 0.831 \\
\hline Men & $21(72 \%)$ & $233(83 \%)$ & $307(89 \%)$ & 0.012 \\
\hline Body mass index, $\left(\mathrm{kg} / \mathrm{m}^{2}\right)$ & $17.5(16.8-17.8)$ & $22.7(21.2-24.1)$ & $27.7(26.2-30.7)$ & $<0.001$ \\
\hline Hypertension & $9(30 \%)$ & $80(29 \%)$ & $144(42 \%)$ & 0.002 \\
\hline Diabetes mellitus & $4(14 \%)$ & $52(19 \%)$ & $98(28 \%)$ & 0.007 \\
\hline Dyslipidemia * & $6(21 \%)$ & $111(40 \%)$ & $166(48 \%)$ & 0.004 \\
\hline Smoker & $16(55 \%)$ & $169(61 \%)$ & $210(56 \%)$ & 0.545 \\
\hline Heart failure etiology & & & & 0.234 \\
\hline -Ischemic & $13(45 \%)$ & $180(64 \%)$ & $219(64 \%)$ & \\
\hline -Idiopathic & $11(38 \%)$ & $71(25 \%)$ & $96(28 \%)$ & \\
\hline -Other & $5(17 \%)$ & $28(10 \%)$ & $29(8 \%)$ & \\
\hline Heart failure duration, (months) & $66.9(5.1-137.2)$ & $30.4(1.1-154.2)$ & $76.2(4.7-176.2)$ & 0.006 \\
\hline Ventricular arrhythmia & $4(14 \%)$ & $81(29 \%)$ & $138(40 \%)$ & $<0.001$ \\
\hline Supra-ventricular arrhythmia & $9(31 \%)$ & $118(42 \%)$ & $175(51 \%)$ & 0.025 \\
\hline
\end{tabular}

\begin{tabular}{lllll}
\hline Left ventricular ejection fraction $\quad 20.0(13.7-25.0)$ & $20.0(15.0-25.0)$ & $20.0(15.0-25.0)$ & 0.710
\end{tabular}
before LVAD, (\%)

\begin{tabular}{lllllll}
\hline Left & ventricular & end-diastolic & $69.0(60.0-72.0)$ & $68.0(62.0-72.2)$ & $71.0(65.0-77.0)$ & $<0.001$
\end{tabular}
diameter before LVAD, (mm)

\begin{tabular}{lcccc}
\hline Creatinine, $(\mu \mathrm{mol} / \mathrm{L})$ & $105.0(78.0-132.2)$ & $112.0(82.5-148.0)$ & $119.0(89.0-147.2)$ & 0.202 \\
Serum sodium, $(\mathbf{m m o l} / \mathbf{L})$ & $136.0(131.7-139.0)$ & $135.5(132.0-139.0)$ & $136.0(132.0-139.0)$ & 0.944
\end{tabular}




\section{Drugs before LVAD implantation}

-Beta-blockers

$18(62 \%)$

$168(60 \%)$

$237(69 \%)$

0.074

-Angiotensin converting enzyme

inhibitors/angiotensin-receptor

blockers

$19(65 \%)$

$164(59 \%)$

$237(69 \%)$

0.032

-Mineralocorticoid receptor

antagonist

$19(65 \%)$

$135(48 \%)$

$202(59 \%)$

0.017

-Amiodarone

$10(34 \%)$

$119(43 \%)$

$155(45 \%)$

0.502

Implantable

cardioverter

$13(45 \%)$

$158(56.6 \%)$

$232(67 \%)$

0.003

defibrillator prior to LVAD

Cardiac resynchronization

$6(21 \%)$

$74(26.5 \%)$

$118(34 \%)$

0.056

therapy prior to LVAD

\section{LVAD}

-HeartMate II

-HeartWare

-Jarvik2000

Indication

-Bridge to transplantation

-Destination therapy

-Bridge to decision/recovery

Surgery combined with LVAD

Temporary right extra corporeal

life support during surgery

$\begin{array}{lcc}18(62 \%) & 203(73 \%) & 254(74 \%) \\ 7(24 \%) & 58(21 \%) & 62(18 \%) \\ 4(14 \%) & 18(6 \%) & 28(8 \%)\end{array}$

$17(59 \%) \quad 162(58 \%) \quad 208(60 \%)$

$11(38 \%) \quad 109(39 \%)$

$127(37 \%)$

$1(3 \%)$

$8(3 \%)$

$9(2 \%)$ 
days)

Total days in intensive care unit

$15.0(12.0-42.7)$

$13.0(8.0-23.0)$

$16.0(10.030 .0)$

0.025

Total days in hospital $49.0(32.0-82.5)$

$40.0(28.0-57.0)$

$42.0(31.0-58.2)$

0.217

* Dyslipidemia is define as having a high plasma triglyceride concentration and/or a high plasma LDL cholesterol and/or a low HDL (protective) cholesterol 
Table 2: Outcomes between patients with low, normal and high BMI

\begin{tabular}{|c|c|c|c|c|}
\hline Variable & $\begin{array}{l}\text { Body Mass index } \\
\qquad \begin{array}{c}\leq 18.5 \mathrm{~kg} / \mathrm{m}^{2} \\
(\mathrm{n}=29)\end{array}\end{array}$ & $\begin{array}{l}\text { Body Mass index } \\
\begin{array}{c}18.5-24.99 \mathrm{~kg} / \mathrm{m}^{2} \\
(\mathrm{n}=279)\end{array}\end{array}$ & 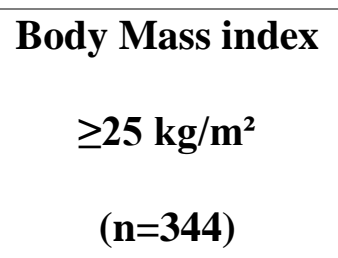 & p Value \\
\hline Total death & $14(48 \%)$ & $105(38 \%)$ & $172(50 \%)$ & 0.008 \\
\hline Cause of death & & & & 0.052 \\
\hline -Cardiovascular & $5(36 \%)$ & $39(37 \%)$ & $81(47 \%)$ & \\
\hline -Non-cardiovascular & $9(64 \%)$ & $62(59 \%)$ & $91(53 \%)$ & \\
\hline -Unknown & $0(0 \%)$ & $4(5 \%)$ & $0(0 \%)$ & \\
\hline Heart transplantation & $7(24 \%)$ & $95(34 \%)$ & $97(28 \%)$ & 0.215 \\
\hline LVAD thrombosis & $1(3 \%)$ & $31(11 \%)$ & $52(15 \%)$ & 0.100 \\
\hline Stroke & $2(7 \%)$ & $34(12 \%)$ & $52(15 \%)$ & 0.322 \\
\hline Bleeding & $7(24 \%)$ & $47(17 \%)$ & $58(17 \%)$ & 0.596 \\
\hline -Cerebral bleeding & $4(14 \%)$ & $17(6 \%)$ & $15(4 \%)$ & 0.088 \\
\hline -Digestive bleeding & $2(7 \%)$ & $18(6 \%)$ & $27(8 \%)$ & 0.797 \\
\hline -Subcutaneous & $0(0 \%)$ & $3(1 \%)$ & $7(2 \%)$ & 0.494 \\
\hline -Other & $1(3 \%)$ & $5(1 \%)$ & $13(4 \%)$ & 0.336 \\
\hline Percutaneous driveline infection & $8(28 \%)$ & $78(28 \%)$ & $85(25 \%)$ & 0.648 \\
\hline LVAD replacement & $0(0 \%)$ & $12(4 \%)$ & $21(15 \%)$ & $<0.001$ \\
\hline Cause for LVAD replacement: & & & & 0.404 \\
\hline -LVAD thrombosis & - & $8(67 \%)$ & $15(71 \%)$ & \\
\hline -LVAD dysfunction & - & $3(25 \%)$ & $2(9 \%)$ & \\
\hline -Other & - & $1(8 \%)$ & $4(19 \%)$ & \\
\hline
\end{tabular}


Table 3: Multivariate analysis for the predictor of overall mortality in patients with abnormal BMI

\begin{tabular}{lccc}
\hline Variable & $\boldsymbol{\beta}$ coefficient & Multivariable HR (95\% CI) & p-value \\
\hline Age, (years) & 0.005 & $1.01(0.98-1.03)$ & 0.727 \\
\hline Hypertension & 0.572 & $1.77(1.08-2.92)$ & $\mathbf{0 . 0 2 4}$ \\
\hline Dyslipidemia & 0.337 & $1.40(0.85-2.30)$ & 0.183 \\
\hline Total bilirubin $\geq \mathbf{1 6} \boldsymbol{\mu m o l} / \mathbf{L}$ & 0.571 & $1.77(1.11-2.08)$ & $\mathbf{0 . 0 1 6}$ \\
\hline Destination therapy & 0.712 & $2.04(1.14-3.64)$ & $\mathbf{0 . 0 1 6}$ \\
\hline Surgery combined with LVAD & 0.915 & $2.49(1.26-4.95)$ & $\mathbf{0 . 0 0 9}$
\end{tabular}


Figure 1

A

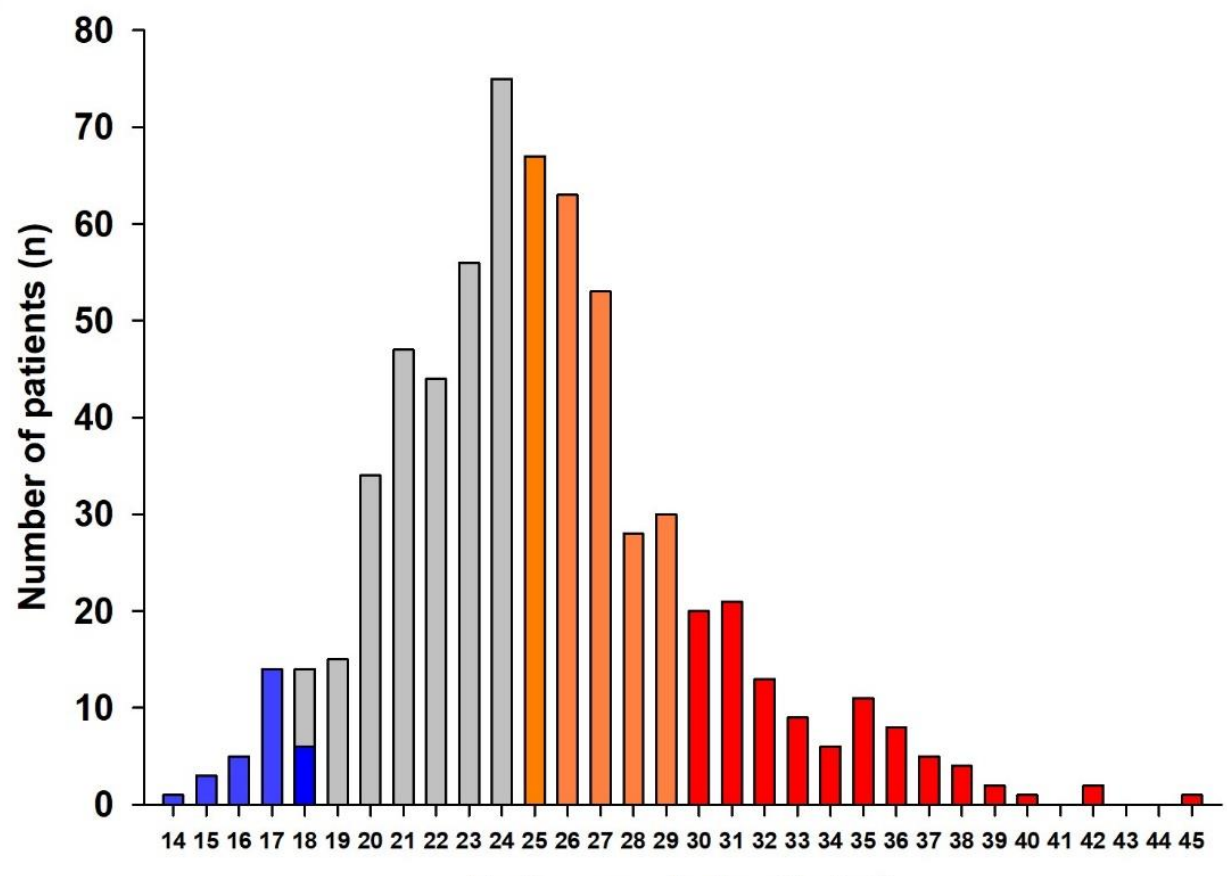

B

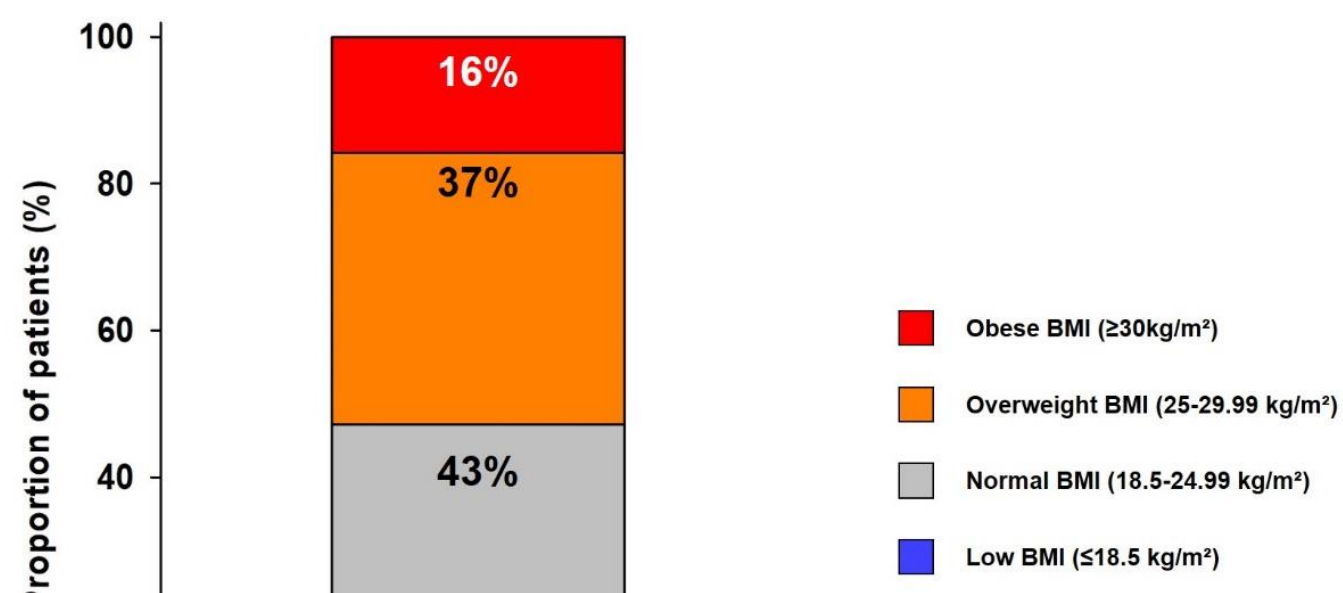


Figure 2

A

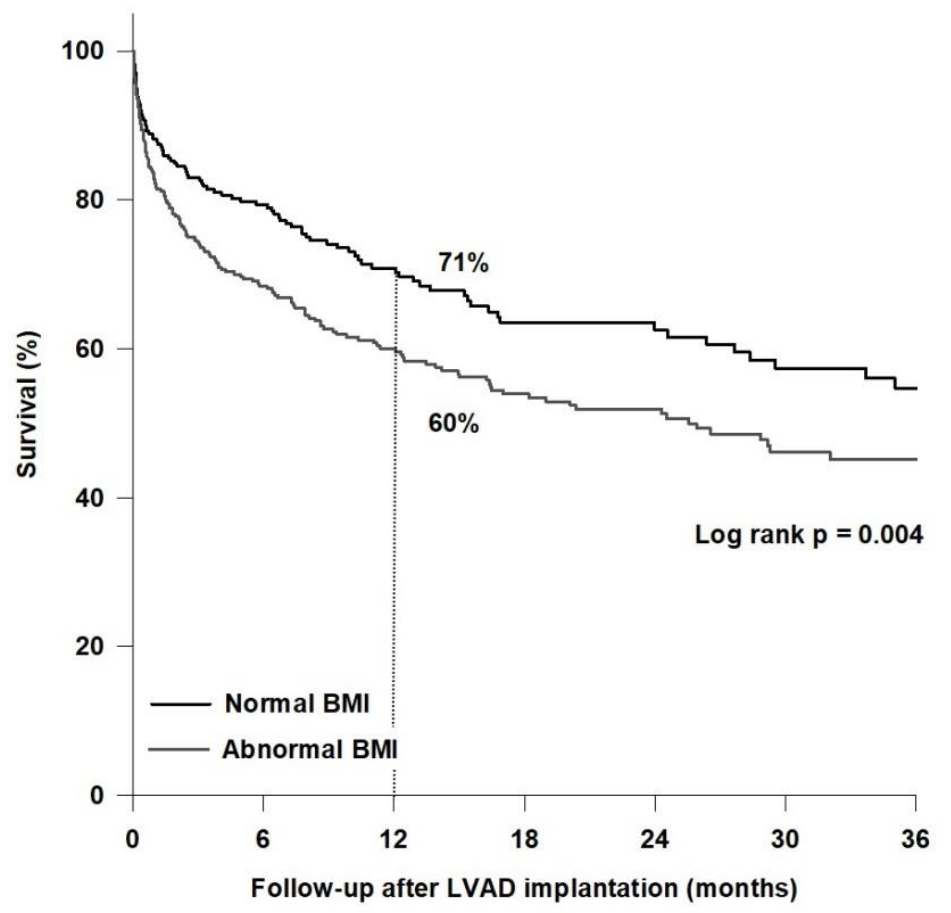

Number at risk

$\begin{array}{llllllll}\text { Normal BMI } & 279 & 186 & 120 & 83 & 64 & 51 & 40\end{array}$

Abnormal BMI

$\begin{array}{lllllll}279 & 186 & 120 & 83 & 64 & 51 & 40 \\ 373 & 216 & 147 & 111 & 87 & 54 & 37\end{array}$

B

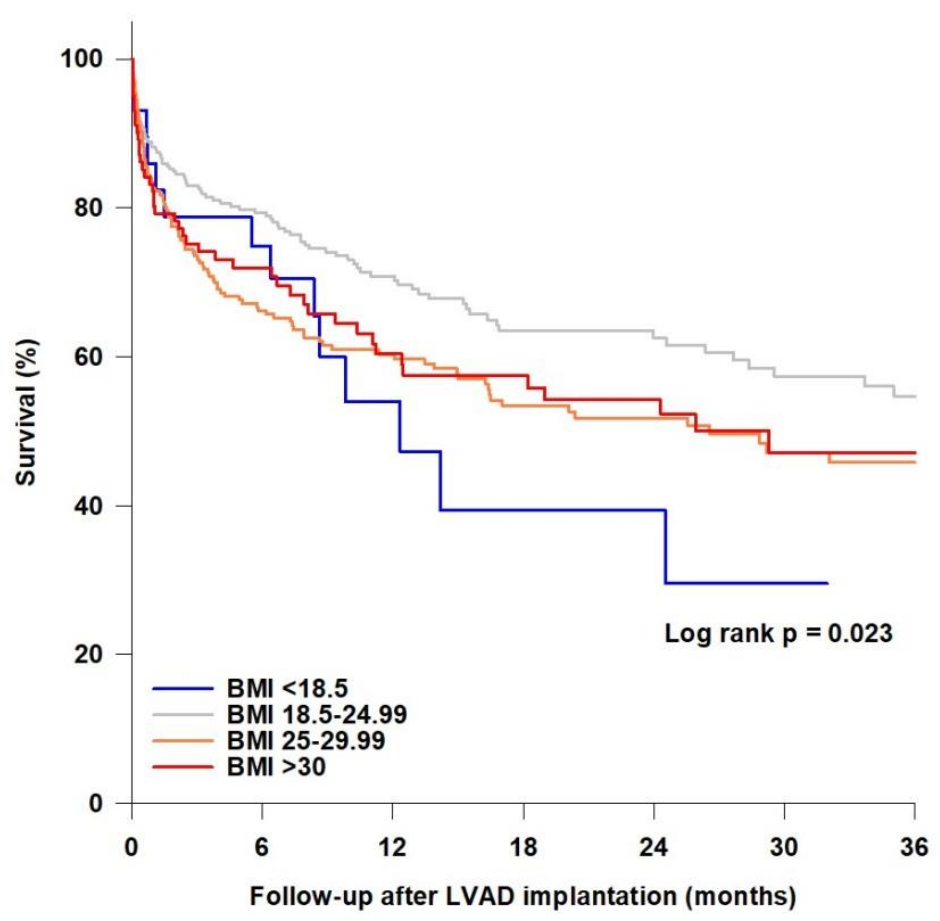

Number at risk

$\begin{array}{rccccccc}B M I \leq 18.5 & 29 & 17 & 8 & 5 & 4 & 2 & 0 \\ B M I 25-29.99 & 241 & 137 & 96 & 71 & 53 & 38 & 27 \\ B M I \geq 30 & 103 & 62 & 43 & 35 & 30 & 14 & 10\end{array}$


Figure 3

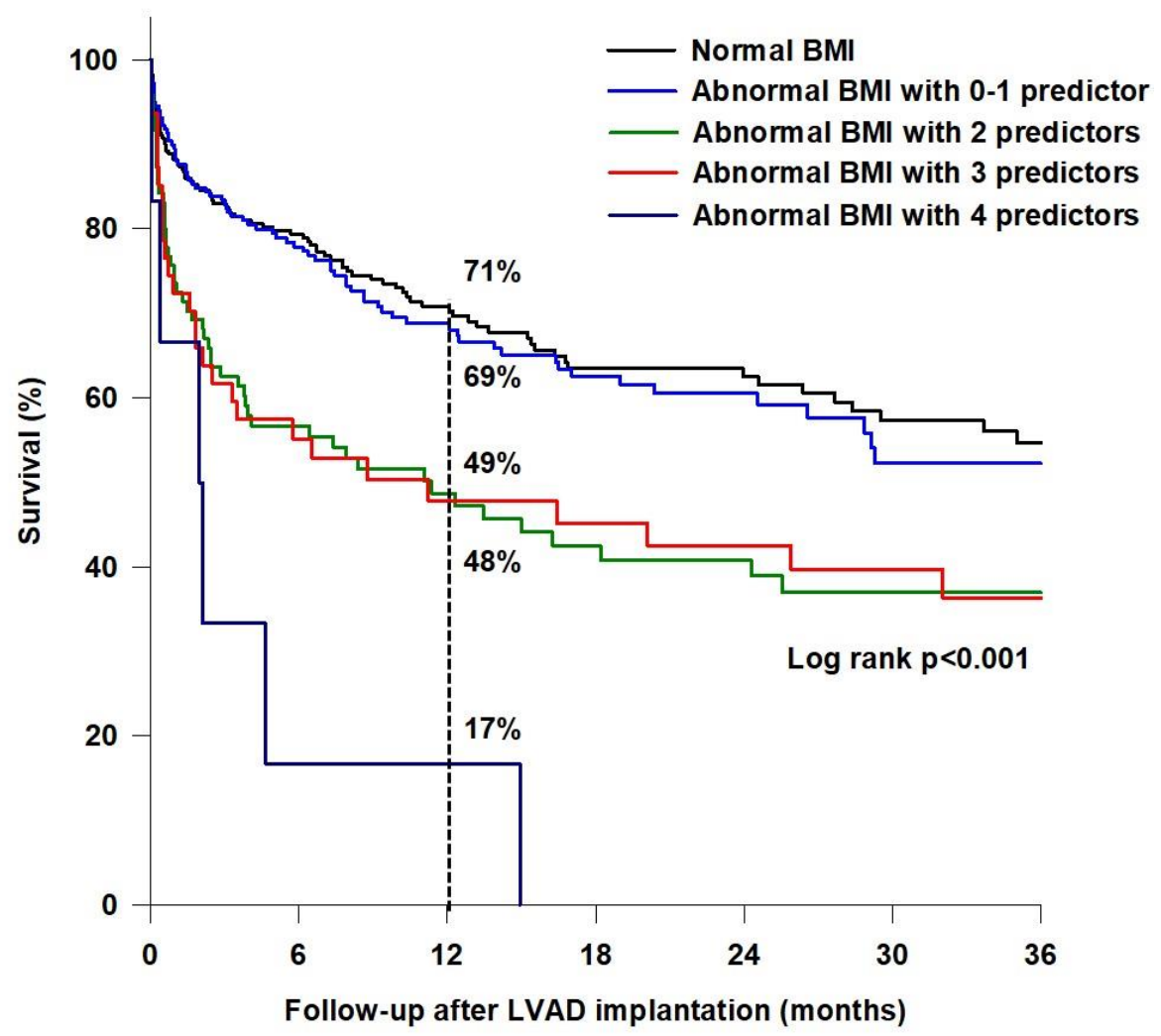

Number at risk

$\begin{array}{rccccccc}\text { Normal BMI } & 279 & 186 & 120 & 83 & 64 & 51 & 40 \\ \text { Abnormal BMI + 0-1 predictor } & 221 & 146 & 95 & 69 & 50 & 27 & 19 \\ \text { Abnormal BMI + 2 predictors } & 97 & 45 & 33 & 25 & 22 & 14 & 9 \\ \text { Abnormal BMI + 3 predictors } & 49 & 24 & 18 & 17 & 15 & 13 & 9 \\ \text { Abnormal BMI + 4 predictors } & 6 & 1 & 1 & 0 & 0 & 0 & 0\end{array}$

